\title{
An Overview of Attitude, Behavior, and Knowledge Level Toward COVID-19 Among Patients Visiting the Otolaryngology Clinic after 1 Year of COVID-19 Pandemic
}

\author{
COVID-19 Pandemisinden Bir Yıl Sonra Otolarengoloji Kliniğine Başvuran Hastalarda \\ COVID-19'a Yönelik Tutum, Davranış ve Bilgi Düzeyine Genel Bir Bakış
}

\section{(1) Çiğdem FIRAT KOCA}

Malatya Turgut Özal University Faculty of Medicine, Department of Otolaryngology Head and Neck Surgery, Malatya, Turkey

\section{Abstract}

Introduction: In December 2019, a new variant of coronavirus was identified in Wuhan city, China. It was named Severe acute respiratory syndromeCoronavirus-2 (SARS-CoV-2), and the disease it caused was defined as Coronavirus disease-2019 (COVID-19). The attitude of people and their knowledge level play an important role in coping with pandemics. Determining the level of public knowledge is also critical for identifying gaps in disease protection and strengthening disease prevention efforts. The present study aimed to describe the general knowledge regarding COVID-19 and the attitude toward the disease among patients applying to an otolaryngology clinic approximately one year after the COVID-19 pandemic. Materials and Methods: We prepared a questionnaire comprising two sections with a total of 19 items. The first section had questions regarding demographic data including age, sex, education level, and job, and the second section had questions assessing knowledge and attitude toward COVID-19. Each correct answer was assigned 1 point; incorrect answers or unknown answers were assigned 0 points. A participant could receive a total knowledge score of 0-19; higher scores indicate better knowledge of COVID-19.

Results: A total of 404 participants were included in our study. The median knowledge score among all participants was $15.0 \pm 3.0$. There was a statistically significant difference between primary school and university graduates $(p<0.05)$ and between secondary school and university graduates in terms of knowledge scores $(p=0.012)$. Similar to the primary and secondary school graduates, high school and university graduates differed significantly in terms of knowledge level ( $p=0.0001)$.

Conclusion: The mean rate of correct answers among patients regarding knowledge and perception questions on COVID-19 was 77.67\%. Our results demonstrated that the sample we selected from the patients visiting our otolaryngology clinic had a high COVID-19 knowledge score. The average knowledge score was possibly high in our study owing to the fact that the participants were mostly university graduates (52.5\%).

Keywords: Knowledge, attitude, COVID-19

\section{Öz}

Giriş: Aralık 2019'da Çin'in Wuhan kentinde Şiddetli akut solunum sendromu-Koronavirüs-2 (SARS-COV-2) olarak adlandırılan yeni bir tip Koronavirüs hastalığı (COVID-19) ortaya çıktı ve neden olduğu hastalık COVID-19 olarak tanımlandı. İnsanların tutum ve bilgi düzeyleri bulaşıCı hastalık salgınıyla baş etmede önemli bir role sahiptir. Halkın bilgisinin ve eksikliklerin belirlenmesi ve önleme çabalarının güçlendirilmesi için de kritiktir. Bu çalışmada, kulak burun boğaz kliniğine başvuran hastaların COVID-19 pandemisinden yaklaşık bir yıl sonra genel COVID-19 bilgi ve tutum düzeylerini tanımlamayı amaçladık.

Gereç ve Yöntem: Toplam 19 maddeden oluşan iki bölümden oluşan bir anket hazırladık. İlk bölüm yaş, cinsiyet, eğitim seviyesi, meslek gibi demografik sorularla ilgili, ikinci bölüm ise COVID-19 ile ilgili bilgi ve tutum sorularını içeriyordu. Her doğru cevaba 1 puan yanlış cevaplar veya

Cite this article as: Firat Koca Ç. An Overview of Attitude, Behavior, and Knowledge Level Toward COVID-19 Among Patients Visiting the Otolaryngology Clinic after 1 Year of COVID-19 Pandemic. Mediterr J Infect Microb Antimicrob. 2021;10:38. 
bilmiyorum olarak verilen cevaplar 0 puan verildi. Bir katılımcı 0 ile 19 arasında değişen bir toplam bilgi puanı alabiliyor iken; yüksek puanlar COVID-19 hakkında daha iyi bilgi sahibi olduğunu gösterir özellikteydi.

Bulgular: Çalışmamıza toplamda 404 katıımcı dahil edildi. Katılımcıların ortanca bilgi puanı 15,0 3,0 idi. Bilgi puanları açısından ilkokul ve üniversite mezunları $(p<0,05)$ ile ortaokul ve üniversite mezunları arasında istatistiksel olarak anlamlı fark vardı $(p=0,012)$. İlkokul ve ortaokul mezunlarına benzer şekilde, lise ve üniversite mezunları arasında bilgi düzeyi açısından istatistiksel olarak anlamlı bir farklılık vardı ( $p=0,0001)$.

Sonuç: Çalışmamızda hastaların COVID-19 ile ilgili bilgi ve algılama sorularına doğru cevap verme oranı ortalama \%77,67 idi. Analiz sonuçları, kulak burun boğaz kliniğimize başvuran hastalardan seçtiğimiz grupta COVID-19 ile ilgili yüksek bilgi puanına sahip olduğunu gösterdi. Çalışmamızın yüksek ortalama bilgi puanı, katılımcıların çoğunlukla üniversite mezunu olmasından $(\% 52,5)$ kaynaklanıyor olabilir.

Anahtar Kelimeler: Bilgi, tutum, COVID-19

\section{Introduction}

Severe acute respiratory syndrome (SARS) and Middle East respiratory syndrome (MERS) are the fatal pulmonary diseases caused by coronaviruses. Severe acute respiratory syndromeCoV was first detected in China in 2002-2003, infected approximately 8500 individuals, and had a fatality ratio of 10\%. In 2012, the MERS-CoV outbreak emerged in Saudi Arabia and was three times more fatal than SARS-CoV infection. In December 2019, a new strain of coronavirus appeared in Wuhan city, China; it was named SARS-CoV-2, and the disease it caused was defined as Coronavirus disease-2019 (COVID-19). With rapidly increasing cases, the outbreak evolved into a pandemic, as declared by the World Health Organization (WHO) on March 11, 2020. Although preliminary studies showed that COVID-19 might be transmitted from animals to humans, recent studies suggest that human-to-human transmission can occur via direct contact and respiratory droplets. In addition, it may take 2-14 days for symptoms to appear after exposure ${ }^{[1]}$. Severe acute respiratory syndrome-CoV-2 belongs to the beta-coronavirus family The provisional case fatality rate for COVID-19 declared by $\mathrm{WHO}$ is approximately $3.4 \% 0^{[2]}$.

Of note, public knowledge and awareness are crucial in combating pandemics. In addition, determining the level of public knowledge is critical for identifying gaps in disease protection and strengthening disease prevention efforts ${ }^{[3]}$. Old age, especially >65 years, and co-morbidities such as heart diseases, lung diseases, and diabetes are risk factors for severe COVID-19. Currently, the primary treatment for COVID-19 involves supportive treatment modalities. Hand washing, using personal protective equipment, and avoiding hand-to-face contamination form hygiene practices that need to be opted to prevent COVID-19 ${ }^{[4]}$. In the present study, we aimed to describe the general knowledge regarding COVID-19 and the attitude of patients visiting an otolaryngology clinic approximately 1 year after the COVID-19 pandemic.

\section{Materials and Methods}

The study was conducted at the Otolaryngology Department of Malatya Training and Research Hospital between December
16 and December 30, 2020. The study was performed after obtaining approval from the Ministry of Health, Turkey, and from the ethics committee of Malatya Clinical Research Ethics (approval number: 2020/172). Data were collected using a questionnaire prepared according to the guidelines published by the Centers for Disease Control and Prevention, WHO, and Ministry of Health, Turkey. Participants aged $>18$ years visiting the otolaryngology clinic were included in the study. Initially, we asked all participants if they were aware of the new variant of coronavirus; those who were aware were requested to complete our survey.

The questionnaire comprised two sections, with a total of 19 items. The first section had questions regarding demographics including age, sex, education level, and job, and the second section comprised questions regarding knowledge and attitude toward COVID-19: source from where participants first heard of COVID-19, whether the new coronavirus was contagious, prevention, transmission, incubation period, extra risk situations, isolation, whether the disease could be transmitted to children and young people, prognosis, whether antibiotics were used in COVID-19 treatment and whether consuming garlic and onion could prevent the disease, appropriate mask usage, ways to inactivate the virus, and special information line regarding COVID-19. For all 14 questions, participants were provided the following options to record answers: "yes," "no," and "do not know." Four questions (regarding prevention methods, appropriate mask use, ways to inactivate the virus, special information line) were designed in a multiple-choice format.

Each correct answer was assigned 1 point; incorrect answers or unknown answers were assigned 0 points. A participant could receive a total knowledge score of $0-19$; higher scores indicated better knowledge regarding COVID-19. We divided all participants into two groups: the first group (aged $<30$ years) and the second group (aged $>30$ years). Then, we determined the rate of correctly responding to questions according to age, sex, profession, and educational status. A total of 404 individuals participated in the survey. All procedures were in accordance with the ethical standards of the institutional and/ or national research committee and with the 1964 Helsinki 
Declaration and its later amendments or comparable ethical standards. Written informed consent was obtained from all participating individuals.

\section{Statistical Analysis}

All study data were analyzed using the Statistical Package for Social Sciences (SPSS 17.0) program. Results were expressed as percentage, median, minimum, and maximum values. As the variables were not suitable for the normal distribution of Kolmogorov-Smirnov test statistics $(p<0.05)$, non-parametric test statistics were used. The Mann-Whitney U test was used to compare the two groups, and the Kruskal-Wallis test was used to compare the two groups. In statistical comparisons, an alpha error level of $p<0.05$ was considered significant.

\section{Results}

A total of 404 individuals participated in our study; survey questionnaires were answered face to face. The mean age of participants was 30.3 ( \pm standard deviation: 10.35 ) years, and approximately $60 \%$ of participants were males. In addition, $57.2 \%$ of participants were under the age of 30 years. Demographic characteristics of participants including sex, education, and profession are summarized in Table 1. Of all participants, $47.6 \%$ had university education and $61.1 \%$ had a job. Moreover, $83.9 \%$ of participants first heard about COVID-19 through television and $12.6 \%$ through social media (e.g., Facebook, Twitter, LinkedIn, and Instagram) (Table 2). Answers of patients visiting the otolaryngology clinic to questions regarding knowledge and perception regarding COVID-19 are shown in Table 3. The median knowledge score of participants was $15.0 \pm 3.0$. Table 4

Table 1. Demographic characteristics of patients $(n=404)$

\begin{tabular}{l|l|l}
\hline & Number & Percentage \\
\hline Sex & & \\
Male & 245 & 60.6 \\
Female & 159 & 39.4 \\
\hline Education & & \\
Primary school & 35 & 8.7 \\
Secondary school & 37 & 9.2 \\
High school & 120 & 29.7 \\
University & 212 & 52.5 \\
\hline Profession & & \\
Housewife & 58 & 14.4 \\
Officer & 39 & 9.7 \\
Laborer & 42 & 10.4 \\
Teacher & 26 & 6.4 \\
Police & 30 & 7.4 \\
Student & 87 & 21.5 \\
Tradesman & 55 & 13.6 \\
Healthcare personnel & 28 & 6.9 \\
Security guard & 8 & 2.0 \\
Unemployed & 12 & 3.0 \\
Engineer & 9 & 2.2 \\
Legist & 10 & 2.5 \\
& &
\end{tabular}

Table 2. The source from where participants first heard of COVID-19

\begin{tabular}{l|l|l}
\hline $\begin{array}{l}\text { Where did you hear about COVID-19 } \\
\text { first? }\end{array}$ & Number & Percentage \\
\hline Television & 339 & 83.9 \\
\hline Newspaper & 7 & 1.7 \\
\hline Social media & 51 & 12.6 \\
\hline Family or friends & 7 & 1.7 \\
\hline Total & 404 & 100.0 \\
\hline
\end{tabular}

shows rates of correct and incorrect answers for each item. The median knowledge score was $14 \pm 4$ for primary school graduates, $14 \pm 4.5$ for secondary school graduates, $14 \pm 2.5$ for high school graduates, and $15 \pm 2$ for university graduates.

There was a statistically significant difference between the knowledge scores of primary school and university graduates $(p<0.05)$ and between secondary school and university graduates $(p=0.012)$. Similar to primary and secondary school graduates, high school graduates and university graduates had a statistically significant difference in terms of knowledge level $(p=0.0001)$. No statistically significant difference was noted between secondary, primary, and high school graduates regarding knowledge scores ( $>0.05)$. The median knowledge score of individuals working as tradesmen was $14 \pm 3$ and those working as healthcare personnel was $16 \pm 2.75$.

When the participants were analyzed according to the rate of correctly answering questions based on their professions, we found a statistically significant difference in the knowledge scores of healthcare workers and tradesmen $(p<0.05)$ (Table 5). We analyzed participants aged $<30$ years and those aged $>30$ and found no statistically significantly difference in the knowledge scores between these patient groups (Table 6) ( $p>0.05$ ).

\section{Discussion}

The study was conducted at the Otolaryngology Department of Malatya Training and Research Hospital, the largest and most crowded hospital in Malatya city located in the east of Turkey. In our study, the median knowledge score among participants was 15.0 \pm 3.0 . Knowledge scores significantly differed by educational levels, with participants with a university degree having higher scores than those with all other educational levels $(15 \pm 2)$. The knowledge scores differed significantly between primary school and university graduates $(p<0.05)$ and between secondary school and university graduates $(p=0.012)$. Similar to the difference between primary and secondary school graduates, there was a statistically significant difference between high school and university graduates in terms of their knowledge level $(p=0.0001)$. 
Table 3. Responses to questions on COVID-19 knowledge and perception among participants visiting otolaryngology clinic (n=404)

\begin{tabular}{|c|c|c|c|}
\hline & & Number & Percentage \\
\hline Q1- Is the new type corona virus contagious? & $\begin{array}{l}\text { Yes } \\
\text { No } \\
\text { I do not know }\end{array}$ & $\begin{array}{l}374 \\
4 \\
26\end{array}$ & $\begin{array}{l}92.6 \\
1.0 \\
6.4 \\
\end{array}$ \\
\hline 02- What to do to protect yourself from the virus? & $\begin{array}{l}\text { Hand washing } \\
\text { Hand washing + wearing mask } \\
\text { Hand washing + wearing mask + } \\
\text { maintaining distance } \\
\text { I do not know }\end{array}$ & $\begin{array}{l}8 \\
21 \\
373 \\
2 \\
\end{array}$ & $\begin{array}{l}2.0 \\
5.2 \\
92.3 \\
0.4 \\
\end{array}$ \\
\hline $\begin{array}{l}\text { 03- Could the transmission of the new coronavirus strain occur via cough and } \\
\text { sneeze? }\end{array}$ & $\begin{array}{l}\text { Yes } \\
\text { No } \\
\text { I do not know }\end{array}$ & $\begin{array}{l}263 \\
96 \\
45\end{array}$ & $\begin{array}{l}65.1 \\
23.8 \\
11.1\end{array}$ \\
\hline Q4- Could hand contact with mouth, nose, and eyes spread the disease? & $\begin{array}{l}\text { Yes } \\
\text { No } \\
\text { I do not know }\end{array}$ & $\begin{array}{l}370 \\
18 \\
16 \\
\end{array}$ & $\begin{array}{l}91.6 \\
4.5 \\
4.0 \\
\end{array}$ \\
\hline 05- Fever, sore throat, cough, and dyspnea are the main symptoms of the disease & $\begin{array}{l}\text { Yes } \\
\text { No } \\
\text { I do not know }\end{array}$ & $\begin{array}{l}376 \\
11 \\
17\end{array}$ & $\begin{array}{l}93.1 \\
2.7 \\
4.2 \\
\end{array}$ \\
\hline Q6- It may take 2-14 days for symptoms to appear after contact with the virus & $\begin{array}{l}\text { Yes } \\
\text { No } \\
\text { I do not know }\end{array}$ & $\begin{array}{l}328 \\
21 \\
55 \\
\end{array}$ & \begin{tabular}{l|}
81.2 \\
5.2 \\
13.6 \\
\end{tabular} \\
\hline 07- The disease can be more serious in patients with chronic diseases & $\begin{array}{l}\text { Yes } \\
\text { No } \\
\text { I do not know }\end{array}$ & $\begin{array}{l}372 \\
9 \\
23\end{array}$ & $\begin{array}{l}92.1 \\
2.2 \\
5.7 \\
\end{array}$ \\
\hline Q8- Older people are more susceptible to the disease & $\begin{array}{l}\text { Yes } \\
\text { No } \\
\text { I do not know }\end{array}$ & $\begin{array}{l}362 \\
20 \\
22\end{array}$ & $\begin{array}{l}89.6 \\
5.0 \\
5.4\end{array}$ \\
\hline 09- Crowded places pose extra risk for spread of COVID-19 & $\begin{array}{l}\text { Yes } \\
\text { No } \\
\text { I do not know }\end{array}$ & $\begin{array}{l}387 \\
9 \\
8 \\
\end{array}$ & $\begin{array}{l}95.8 \\
2.2 \\
2.0 \\
\end{array}$ \\
\hline Q10- Patients with COVID-19 should be isolated to not infect others & $\begin{array}{l}\text { Yes } \\
\text { No } \\
\text { I do not know }\end{array}$ & $\begin{array}{l}384 \\
6 \\
14 \\
\end{array}$ & $\begin{array}{l}95.0 \\
1.5 \\
3.5\end{array}$ \\
\hline Q11- Human-to-human COVID-19 transmission can occur via direct contact & $\begin{array}{l}\text { Yes } \\
\text { No } \\
\text { I do not know }\end{array}$ & $\begin{array}{l}307 \\
73 \\
24\end{array}$ & $\begin{array}{l}76.0 \\
18.1 \\
5.9\end{array}$ \\
\hline Q12- COVID-19 does not infect young people and children & $\begin{array}{l}\text { Yes } \\
\text { No } \\
\text { I do not know }\end{array}$ & $\begin{array}{l}39 \\
342 \\
23\end{array}$ & $\begin{array}{l}9.6 \\
84.6 \\
5.7\end{array}$ \\
\hline 013- COVID-19 always results in death & $\begin{array}{l}\text { Yes } \\
\text { No } \\
\text { I do not know }\end{array}$ & $\begin{array}{l}55 \\
326 \\
23 \\
\end{array}$ & $\begin{array}{l}13.6 \\
80.7 \\
5.7 \\
\end{array}$ \\
\hline 014- COVID-19 can be asymptomatic & $\begin{array}{l}\text { Yes } \\
\text { No } \\
\text { I do not know }\end{array}$ & $\begin{array}{l}253 \\
86 \\
65\end{array}$ & $\begin{array}{l}62.6 \\
21.3 \\
16.1\end{array}$ \\
\hline Q15- Using antibiotics prevents and cures COVID-19 & $\begin{array}{l}\text { Yes } \\
\text { No } \\
\text { I do not know }\end{array}$ & $\begin{array}{l}68 \\
225 \\
111 \\
\end{array}$ & $\begin{array}{l}16.8 \\
55.7 \\
27.5\end{array}$ \\
\hline Q16- Consuming garlic and onion prevents COVID-19 & $\begin{array}{l}\text { Yes } \\
\text { No } \\
\text { I do not know }\end{array}$ & $\begin{array}{l}93 \\
199 \\
112\end{array}$ & $\begin{array}{l}23.0 \\
49.3 \\
27.7\end{array}$ \\
\hline
\end{tabular}




\begin{tabular}{|c|c|c|c|}
\hline Q17- What can inactivate the coronavirus? & $\begin{array}{l}\text { Chlorine } \\
\text { Disinfectant } \\
\text { Water + detergent } \\
\text { Water } \\
\text { I do not know }\end{array}$ & $\begin{array}{l}11 \\
171 \\
143 \\
10 \\
69\end{array}$ & $\begin{array}{l}2.7 \\
42.3 \\
35.4 \\
2.5 \\
17.1\end{array}$ \\
\hline Q18- What is the COVID-19 information line in Turkey? & $\begin{array}{l}112 \\
182 \\
184 \\
\text { Presidential communication } \\
\text { center }\end{array}$ & $\begin{array}{l}101 \\
108 \\
177 \\
18\end{array}$ & $\begin{array}{l}25.0 \\
26.7 \\
43.8 \\
4.4\end{array}$ \\
\hline Q19- How to wear a face mask? & $\begin{array}{l}\text { Just closing mouth } \\
\text { Closing mouth }+ \text { nose } \\
\text { Closing mouth }+ \text { nose }+ \text { chin }\end{array}$ & $\begin{array}{l}6 \\
76 \\
322\end{array}$ & $\begin{array}{l}1.5 \\
18.8 \\
79.7\end{array}$ \\
\hline
\end{tabular}

COVID-19: Coronavirus disease-2019

Fever, fatigue, dry cough, malaise, and breathing difficulty are the main symptoms of COVID-19 $9^{[5]}$. It is crucial to know the symptoms and high-risk conditions as well as to avoid contact with an infected patient and contaminated surfaces. Washing hands and maintaining social distance are the major precautions against the viral infection ${ }^{[2]}$. Older people and people with chronic illnesses are the most vulnerable population to COVID-19. Thus, people should be aware of who in their social network is at the most risk. The world has gained great experience about COVID-19 since the pandemic began. During the first year of the pandemic itself, researchers rapidly gathered information on the origin, transmission, and progression of the disease ${ }^{[6]}$.

Government have executed numerous efforts to control the transmission speed of COVID-19. These efforts include the following: asking people to stay at home, not to prefer public transportation to prevent any close contact, encouraging the use of masks, and maintaining a suggested distance from people in crowded places; in addition, via various media sources, including television and popular social media platforms, the governments suggested exercises, healthy food consumption habits, and lifestyle modifications for people staying at home ${ }^{[7]}$.

In Turkey, the first case of COVID-19 was identified on March 10,2020 , and the first death was recorded on March 17, 2020[8]. The Turkish government undertook several precautions against COVID-19 before the disease spread throughout the country. An operation center and a Science Board was created in the first few weeks of January 2020 to closely monitor developments. On January 14, the Turkish Ministry of Health published the "COVID-19 Disease Guide" to provide current and updated information regarding COVID-19 to the society. This guide is regularly updated according to recent developments. After the identification of the first COVID-19 case on March 10, the government announced a curfew for individuals older than 65 years and younger than 20 years from March 22 to April 6 2020. Wearing masks in public areas was made compulsory. Ayhan Başer et al ${ }^{[9]}$ found that Turkish individuals had adequate awareness and a positive attitude toward COVID-19. In addition,
Honarvar et al. ${ }^{[10]}$ determined that $50 \%$ of study participants thought that COVID-19 was a serious, fatal disease.

Governments should maintain public health education programs to strengthen knowledge and awareness among the public through multiple channels, especially social media platforms and television. Yue et al. ${ }^{[1]]}$ demonstrated that age, sex, education, and marital status were the factors influencing COVID-19 knowledge level and that married participants had a lower level of knowledge than unmarried residents.

We analyzed patients aged $<30$ years (first group) and $>30$ years (second group) and examined knowledge scores; we found no significant difference between these groups.

According to KONDA Barometer report, at the beginning of the pandemic in Turkey (March 7-8), people choose television $(88 \%)$, social media $(63 \%)$, virtual press $(59 \%)$, and friends $(42 \%)$ as their sources of information regarding COVID-19 ${ }^{[0,12]}$. Like in the study by Sari et al. ${ }^{[7]}$ and as in the KONDA Barometer report ${ }^{[12]}$, the most widely used sources of information in our study were television (83.9\%) and social media (12.6\%). In the study by Chen et al. ${ }^{[13]}$, participants declared that they received COVID-19 information from social media. In addition, Yue et al. ${ }^{[11]}$ demonstrated that social media was the most important source of COVID-19 information. Olaimat et al. ${ }^{[4]}$ reported that the students in their study chose internet and social media as the main source of COVID-19 information.

Similarly, Alzoubi et al. ${ }^{[14]}$ found that Mutah university students used social media for gaining knowledge regarding COVID-19.

Since the beginning of the COVID-19 pandemic, studies have been conducted to assess the knowledge and attitude levels of people. Chen et al. ${ }^{[13]}$ showed that people had appropriate awareness regarding the major symptoms and transmission of disease as well as regarding proper use of mask, washing hands, and COVID-19 treatment; however, participants had low awareness regarding typical symptoms. Li et al. ${ }^{[15]}$ demonstrated that Chinese people 
Table 4. Rate of correctly and incorrectly answering questions regarding COVID-19 knowledge and perception among patients $(n=404)$

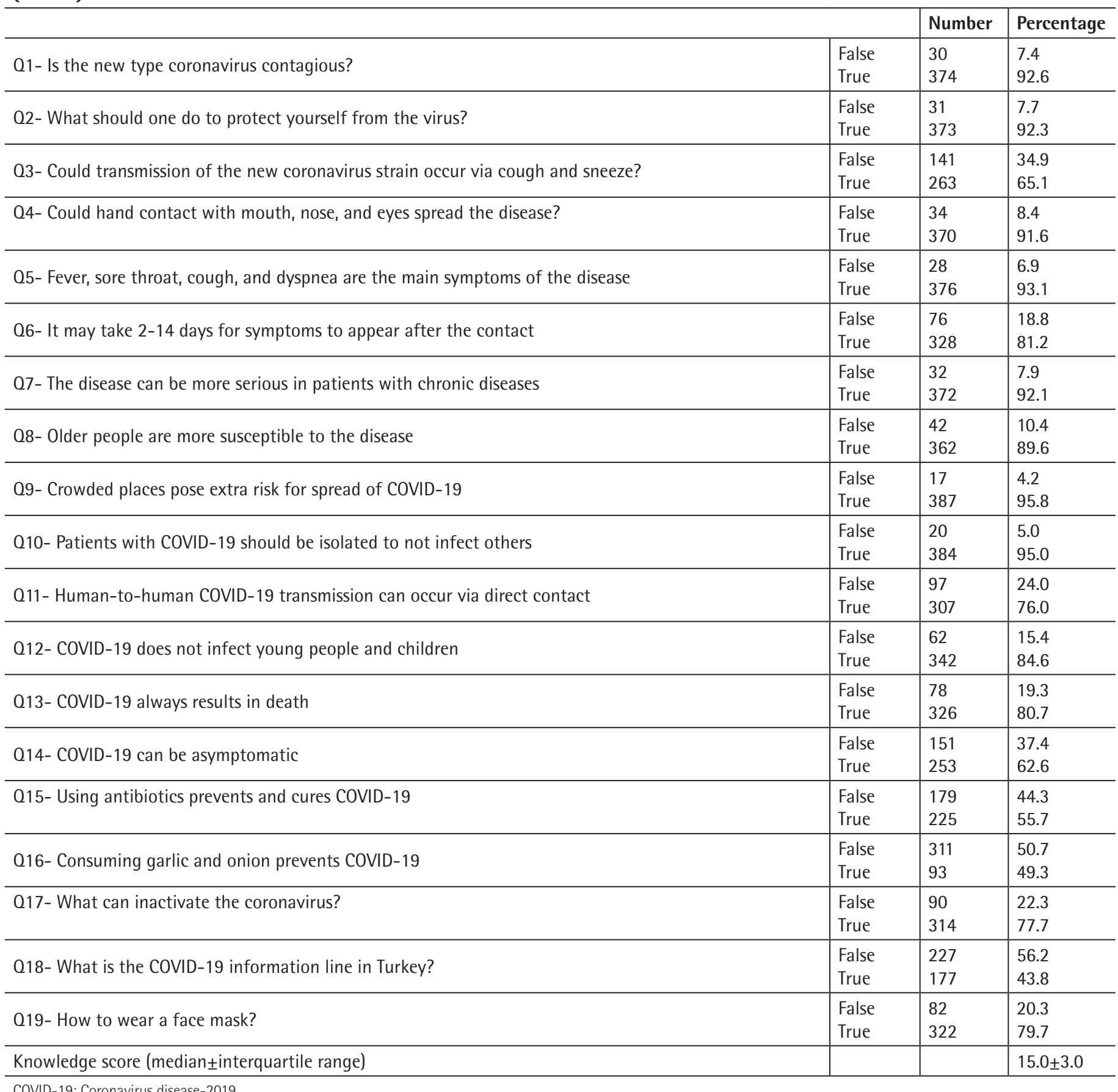

COVID-19: Coronavirus disease-2019

had a moderate level of COVID-19 knowledge. In the study by Yue et al. ${ }^{[11]}$, the knowledge level of participants as $61.9 \%$. Reuben et al. ${ }^{[5]}$ showed that the level of knowledge regarding COVID-19 among Nigerians was appropriate. In another study, Al-Hanawi et al. ${ }^{[3]}$ demonstrated that Saudi residents, especially women, had appropriate knowledge level, had positive attitudes, and good practices toward COVID-19. Olaimat et al. ${ }^{[4]}$ reported that the overall COVID-19 knowledge score among students was $80.1 \%$.
In our study, the mean rate of obtaining correct answers to knowledge and perception questions regarding COVID-19 was 77.67\%. Our results revealed that the sample selected from the patients visiting the otolaryngology clinic had a high level of knowledge score regarding COVID-19. The high average knowledge score in our study may also be attributed to the fact that the participants were mostly university graduates (52.5\%). 
Table 5. Knowledge score of participants according to sex, education, and profession

\begin{tabular}{|c|c|c|c|c|}
\hline & (Median \pm interquartile range) & Minimum-maximum & Test statistic & $p$ value \\
\hline $\begin{array}{l}\text { Sex } \\
\text { Male } \\
\text { Female }\end{array}$ & $\begin{array}{l}15 \pm 3 \\
15 \pm 2\end{array}$ & $\begin{array}{l}4-19 \\
3-19\end{array}$ & -0.618 & 0.537 \\
\hline $\begin{array}{l}\text { Education } \\
\text { Primary school } \\
\text { Secondary school } \\
\text { High school } \\
\text { University }\end{array}$ & $\begin{array}{l}14 \pm 4 \\
14 \pm 4.5 \\
14 \pm 2.5 \\
15 \pm 2\end{array}$ & $\begin{array}{l}7-19 \\
4-18 \\
3-19 \\
8-18 \\
\end{array}$ & 18.217 & $0.0001^{* *}$ \\
\hline $\begin{array}{l}\text { Profession } \\
\text { Housewife } \\
\text { Officer } \\
\text { Laborer } \\
\text { Teacher } \\
\text { Police } \\
\text { Student } \\
\text { Tradesman } \\
\text { Healthcare personnel } \\
\text { Security guard } \\
\text { Unemployed } \\
\text { Engineer } \\
\text { Legist }\end{array}$ & $\begin{array}{l}15 \pm 3 \\
15 \pm 3 \\
14 \pm 4 \\
16 \pm 1.5 \\
14 \pm 3 \\
15 \pm 3 \\
14 \pm 3 \\
16 \pm 2.75 \\
15.5 \pm 2.5 \\
14 \pm 2 \\
14 \pm 2 \\
15.5 \pm 1.25\end{array}$ & $\begin{array}{l}3-19 \\
11-18 \\
7-17 \\
8-18 \\
10-17 \\
9-18 \\
4-18 \\
13-18 \\
4-19 \\
11-17 \\
13-18 \\
10-17\end{array}$ & 24.722 & 0.010 \\
\hline
\end{tabular}

Table 6. Comparison of knowledge score between age groups

\begin{tabular}{l|l|l|l}
\hline \multirow{2}{*}{ Knowledge score } & \multicolumn{2}{|l|}{ Age } & p value \\
\cline { 2 - 3 } & $\mathbf{< 3 0}$ years & $>\mathbf{3 0}$ years & \\
\hline Mean & 14.5108 & 14.3699 & \\
\hline Median & 15.0000 & 15.0000 & \\
\hline $\begin{array}{l}\text { Standard } \\
\text { deviation }\end{array}$ & 2.20644 & 2.63510 & \multirow{2}{*}{0.960} \\
\hline Minimum & 7.00 & 3.00 & \\
\hline Maximum & 19.00 & 19.00 & \\
\hline $\begin{array}{l}\text { Interquartile } \\
\text { range }\end{array}$ & 3.00 & 3.00 & \\
\hline
\end{tabular}

There is no statistical significance between groups in terms of knowledge score $(p>0.05)$

Zhong et al. ${ }^{[16]}$ conducted a survey in China and revealed that the knowledge level among participants was 90\%. This high level may be attributed to the highly educated participants enrolled in their study.

In contrast, Srichan et al. ${ }^{[17]}$ found that Thai people had poor knowledge about COVID-19.

In the study by Mbachu et al. ${ }^{[18]}$ conducted among healthcare workers in South-Eastern Nigeria, a great majority of participants $(88.59 \%)$ had good knowledge and good preventive practices (81.39\%). Qadah ${ }^{[19]}$ determined that $88 \%$ of healthcare workers had positive knowledge and attitude toward COVID-19. In addition, in the study by Bates et al. ${ }^{[6]}$, Ecuadorian participants had a substantially lower rate of knowledge about COVID-19.
Proper nutrition supports body immunity. Several healthy foods can induce immunomodulatory effects and their benefits cannot be ignored ${ }^{[7]}$. In their study, Gohel et al. ${ }^{[1]}$ found that approximately $30 \%$ of participants considered that eating garlic could protect against COVID-19. In contrast, 33\% of the Egyptian population assessed by Abdelhafiz et al. ${ }^{[20]}$ incorrectly believed that consuming garlic can prevent the spread of COVID-19. Unfortunately, 23\% of participants in our study believed that consuming garlic and onion could prevent COVID-19, similar to the findings by Gohel et al. ${ }^{[1]}$ and Abdelhafiz et al. ${ }^{[20]}$ Moreover, $27.7 \%$ of participants in our study were unaware of whether consuming garlic and onion could protect against COVID-19. Although herbal foods such as garlic and onion have been shown to have beneficial effects on the immune system in humans, we found no clinical studies providing evidence on the direct protective effect of these foods against COVID-19.

In Turkey, the Turkish Ministry of Health established a communication line that served as a direct consultation platform for the public during the COVID-19 pandemic. By directly dialing the phone number 184, people received counseling on COVID-19. In our study, $43.8 \%$ of participants were aware that they could get such a consultancy service.

To date, several countries have developed vaccines for COVID-19, and studies have provided promising results on the safety and efficacy of these vaccines. However, this does not mean that we will give up on protective measures. In order for vaccines to work, the community needs to attain a large degree of immunity, and this requires considerable people to be vaccinated and more time as well as living with protective measurements for a while. 
Our study is with few limitations. Our study sample was small; thus, our findings may be supported by large patient groups in future studies. We used a self-reporting questionnaire, and the responses were subject to the participant's honesty and, partly, recall ability; this parameter may have attributed recall bias.

\section{Conclusion}

In conclusion, our results suggest that the sample selected from the patients visiting our otolaryngology clinic had a high level of knowledge score regarding COVID-19 and showed positive knowledge and attitude toward the disease.

\section{Ethics}

Ethics Committee Approval: All procedures performed in studies involving human participants were in accordance with the ethical standards of the institutional and/or national research committee and with the 1964 Helsinki Declaration and its later amendments or comparable ethical standards. The study was conducted after obtaining approval of the Ministry of Health in Turkey and approval of the ethics committee in Malatya Clinical Research Ethics (Ethical number 2020/172).

Informed Consent: Was obtained from all participants included in this study.

Peer-review: Externally and internally peer-reviewed.

Financial Disclosure: The author declared that this study received no financial support.

\section{References}

1. Gohel KH, Patel PB, Shah PM, Patel JR, Pandit N, Raut A. Knowledge and perceptions about COVID-19 among the medical and allied health science students in India: An online cross-sectional survey. Clin Epidemiol Glob Health. 2021;9:104-9.

2. Kebede $Y$, Yitayih $Y$, Birhanu Z, Mekonen S, Ambelu A. Knowledge, perceptions and preventive practices towards COVID-19 early in the outbreak among Jimma University Medical Center visitors, Southwest Ethiopia. PLoS One. 2020;15:e0233744.

3. Al-Hanawi MK, Angawi $\mathrm{K}$, Alshareef $\mathrm{N}$, Qattan AMN, Helmy HZ, Abudawood Y, Alqurashi M, Kattan WM, Kadasah NA, Chirwa GC, Alsharqi 0 . Knowledge, attitude and practice toward COVID-19 among the public in the kingdom of saudi arabia: a cross-sectional study. Front Public Health. 2020;8:217.

4. Olaimat AN, Aolymat I, Shahbaz HM, Holley RA. Knowledge and information sources about COVID-19 among university students in Jordan: a cross-sectional study. Front Public Health. 2020;8:254.

5. Reuben RC, Danladi MMA, Saleh DA, Ejembi PE. knowledge, attitudes and practices towards COVID-19: an epidemiological survey in north-central Nigeria. J Community Health. 2020;7:1-14.

6. Bates BR, Moncayo AL, Costales JA, Herrera-Cespedes CA, Grijalva MJ. Knowledge, attitudes, and practices towards covid-19 among ecuadorians during the outbreak: an online cross-sectional survey. J Community Health. 2020;45:1158-67.

7. Sari DK, Amelia R, Dharmajaya R, Sari LM, Fitri NK. Positive correlation between general public knowledge and attitudes regarding COVID-19 outbreak 1 month after first cases reported in Indonesia. J Community Health. 2021;46:182-9.

8. Aker $S, M ı d ı k$ Ö. The views of medical faculty students in turkey concerning the COVID-19 pandemic. J Community Health. 2020;45:684-8.

9. Ayhan Başer D, Çevik M, Gümüştakim Ş, Başara E. Assessment of individuals' attitude, knowledge and anxiety towards COVID-19 at the first period of the outbreak in Turkey: a web-based cross-sectional survey. Int J Clin Pract 2020;74:e13622.

10. Honarvar B, Lankarani KB, Kharmandar A, Shaygani F, Zahedroozgar M, Rahmanian Haghighi MR, Ghahramani S, Honarvar H, Daryabadi MM, Salavati Z, Hashemi SM, Joulaei H, Zare M. Knowledge, attitudes, risk perceptions, and practices of adults toward COVID-19: a population and field-based study from Iran. Int J Public Health. 2020;65:731-9.

11. Yue $\mathrm{S}$, Zhang J, Cao M, Chen B. Knowledge, attitudes and practices of COVID-19 among urban and rural residents in china: a cross-sectional study. J Community Health 2021;46:286-91.

12. KONDA Barometer Report (2020), 107, 7-8 March, 2020.

13. Chen $Y$, Jin $Y L$, Zhu U, Fang ZM, Wu N, Du MX, Jiang MM, Wang J, Yao YS. [The network investigation on knowledge, attitude and practice about Novel coronavirus pneumonia of the residents in Anhui Province]. Zhonghua Yu Fang Yi Xue Za Zhi. 2020;54:E004. (Article in Chinese) doi: 10.3760/cma.j.issn.0253-9624.2020.0004. Epub ahead of print.

14. Alzoubi $\mathrm{H}$, Alnawaiseh N, Al-Mnayyis A, Abu-Lubada M, Aqel A, AlShagahin H. COVID-19 - knowledge, attitude and practice among medical and non-medical university students in Jordan J. Pure Appl Microbiol. 2020;14:17-24.

15. Li JB, Yang A, Dou K, Wang LX, Zhang MC, Lin XQ. Chinese public's knowledge, perceived severity, and perceived controllability of COVID-19 and their associations with emotional and behavioural reactions, social participation, and precautionary behaviour: a national survey. BMC Public Health. 2020;20:1589.

16. Zhong BL, Luo W, Li HM, Zhang QQ, Liu XG, Li WT, Li Y. Knowledge, attitudes, and practices towards COVID-19 among Chinese residents during the rapid rise period of the COVID-19 outbreak: a quick online cross-sectional survey. Int J Biol Sci. 2020;16:1745-52.

17. Srichan $P$, Apidechkul $T$, Tamornpark $R$, Yeemard $F$, Khunthason $S$, Kitchanapaiboon S, Wongnuch P, Wongphaet A, Upala P. Knowledge, attitudes and preparedness to respond to COVID-19 among the border population of northern Thailand in the early period of the pandemic: a cross-sectional study. WHO South East Asia J Public Health. 2020;9:11825.

18. Mbachu CNP, Azubuike CM, Mbachu II, Ndukwu Cl, Ezeuko AY, Udigwe IB, Nnamani CP, Umeh UM, Ezeagwuna DA, Onah SK, Eze HO, Okereke UC, Orji-Ifeanyi EN. COVID-19 infection: knowledge, attitude, practices, and impact among healthcare workers in a South-Eastern Nigerian state. J Infect Dev Ctries. 2020;14:943-52.

19. Qadah T. Knowledge and attitude among healthcare workers towards COVID-19: a cross sectional study from Jeddah city, Saudi Arabia. J Infect Dev Ctries. 2020;14:1090-7.

20. Abdelhafiz AS, Mohammed Z, Ibrahim ME, Ziady HH, Alorabi M, Ayyad M. Sultan EA. Knowledge, Perceptions, and Attitude of Egyptians Towards the Novel Coronavirus Disease (COVID-19). J Community Health. 2020;21:110. 